\title{
Towards a Better Understanding of a Continuum of Heritage Language Proficiency : The Case of Adolescent Russian Heritage Speakers
}

\section{Minkov, Miriam}

2019

Minkov , M , Kagan , O E , Protassova , E \& Schwarz , M 2019 , ' Towards a Better Understanding of a Continuum of Heritage Language Proficiency : The Case of Adolescent Russian Heritage Speakers ' , Heritage Language Journal, vol. 16 , no. 2 , pp. 211-237 . https://doi.org/10.46538/hlj

http://hdl.handle.net/10138/337217

https://doi.org/10.46538/hlj.16.2.5

Downloaded from Helda, University of Helsinki institutional repository.

This is an electronic reprint of the original article.

This reprint may differ from the original in pagination and typographic detail.

Please cite the original version. 


\title{
Towards a Better Understanding of a Continuum of Heritage Language Proficiency: The Case of Adolescent Russian Heritage Speakers
}

\author{
Miriam Minkov \\ Tel Aviv University \\ Olga E. Kagan \\ UCLA \\ Ekaterina Protassova \\ University of Helsinki \\ Mila Schwartz \\ Oranim Academic College of Education
}

\begin{abstract}
The study presented here has three goals: (1) to identify types of errors in the noun inflectional morphology in Russian as a heritage language among Russian-speaking adolescents in Israel $(n=11)$, the United States $(n=11)$, Finland $(n=14)$, and Germany $(n=9),(2)$ to compare errors in speech production between these groups, and (3) to investigate the impact of Russian language use at home and in educational settings (formal bilingual education versus after-school classes) on the preservation of Russian noun morphology. The participants' speech was elicited through retelling of Mayer and Mayer's (1978) picture book Frog, Where Are You? Case and gender errors in speech production were analyzed qualitatively and quantitatively. The groups were found to be clustered at the opposite ends of a proposed continuum of noun morphology knowledge, with Russian German and Russian Finish bilinguals outperforming their counterparts in Israel and the U.S. The results of the study indicate the advantage of predominantly Russian use at home and formal bilingual schooling for the acquisition of Russian morphology.
\end{abstract}

\section{INTRODUCTION}

The present study investigates the acquisition of Russian noun morphology by Russian Heritage speakers (HSs) with different socio-linguistic characteristics such as the use of Russian at home, after-school classes,,$\underline{1}$ and formal bilingual education. To our knowledge, no research to date has surveyed Russian Heritage Language (HL) acquisition among adolescents from four sociolinguistic contexts as presented here. We chose to focus on Russian HS' competence in two features of noun morphology, case and gender agreement, since their acquisition is particularly challenging for Russian-speaking monolingual children (Ceytlin, 2009, pp. 142-197) and since case and gender errors are a prominent characteristic of the Russian HL (Isurin \& IvanovaSullivan, 2008; Pavlenko, 2009; Polinsky, 2008; Schwartz et al., 2015). The following relevant concepts will be addressed in the theoretical background of our study: heritage speakers, continuum of language proficiency, heritage language educational settings, and family language policy. 


\section{Heritage Language Competence}

Defining heritage speakers, Polinsky and Kagan (2007) note that " $[\mathrm{t}]$ he crucial criterion is that the heritage language was first in the order of acquisition but was not completely acquired because of the individual's switch to another dominant language" (p. 369). Furthermore, Polinsky and Kagan propose to view this population as diverse in terms of their linguistic proficiency and to place HSs on a continuum, which has been used previously to characterize creole languages. The proposed continuum ranges from acrolectal speakers (native-like language proficiency) via mesolectal speakers to basilectal speakers (low language proficiency). At one end of the continuum, we place HSs who lack language skills, but who, nonetheless, are emotionally connected to the language. The basilectal speakers are characterized as those "who grew up with limited or early interrupted exposure to the home language" (p. 14), including individuals who only heard but never responded in their HL, and those who switched to the language of the majority during early childhood. At the other end of the continuum we find HSs with full mastery of the baseline ${ }^{2}$ variant. Between these two extremes, we observe varying levels of HL proficiency.

\section{The Role of Family and Bilingual Schooling in HL Maintenance}

A number of factors influence the individual level of HL proficiency. Kagan (2005) identifies the triad of HS resources that support language acquisition: family-community, including community schools - formal education. Kagan notes that "each of the elements in the triad can have a greater or lesser prominence depending on the language, history of the language group migration and attitude to language preservation, among other factors" (p. 213). The first element of the triadthe family - plays a crucial role in HL maintenance through the Family Language Policy (FLP) (Schwartz, 2010). Traditionally, FLP model is viewed as an interplay of (1) parents' and children's attitudes toward their heritage culture and language, (2) the family's language management, such as the choice of educational settings for children, and (3) the actual practice of language use at home. Every one of the FLP components was found to be of consequence for the level of HL proficiency among children (Schwartz, 2008; Altman, Burstein Feldman, Yitzhaki, Armon Lotem, \& Walters, 2014). In Kagan's framework, however, the first element of the triad, the family, refers mainly to language use in the family, which is the primary resource for language acquisition, while the other two elements of the triad, i.e., community after-school classes and/or formal bilingual educational settings are subsumed under the family language management component of the FLP model. Families may choose to send their children to community schools or enroll them in bilingual school programs, but their choices may be limited by the availability of such opportunities (Schwartz, 2010).

The language of communication among family members at home is reported as the most important part of parents' efforts to transmit their language to their children (Oh \& Fuligni, 2010; Park \& Sarkar, 2007). At the same time, for ideological or practical reasons, the immigrant parents themselves may partially or totally switch to the language of the host community, which in turn influences the children's proficiency in their first language (Nesteruk, 2010; Brown, 2011). For example, to examine the role played by the language of family communication in the maintenance of heritage language, Altman et al. (2014) investigated Russian-speaking families in Israel. In this study, the families were classified as providing strict-Russian, mild-Russian, and pro-bilingual FLPs based on interviews with 65 parents. The study investigated the interaction between parents' reports on their language planning and use at home and on their children's linguistic abilities in 
the HL. The results indicated that the stricter the family policy was at home, as reported by parents, the more Russian use at home was reported by the preschool children. In addition, children in the strict-Russian group rated themselves as speaking Russian significantly better than children in the pro-bilingual group. The study also measured a group effect on the children's language performance: children in the pro-bilingual group performed significantly worse on Russian language tasks compared to those in the strict pro-Russian and mild pro-Russian groups. It is notable that Altman's et al. (2014) study did not examine a connection between such sociolinguistic factors as type of HL education and HL proficiency. In addition, the study's results must be viewed with an understanding that preschool children's language proficiency is subject to change since language dominance tends to change from the home language to the societal language due to the massive input in the societal language received in school. Considering the limitations of this research, the current study focused on a link between the type of HL education and proficiency in HL as indicated by Russian-speaking adolescents' control of the noun inflectional morphology.

Educational settings include community after-school classes and formal bilingual education in mainstream schools. Garcia, Zakharia and Otcu (2013) defined the difference between after-school classes and formal bilingual education as following: the former is usually supplementary afternoon or weekend classes with limited HL teaching hours, while the latter as a rule refers to utilization of two languages (HL and societal language) to some degree as means of instruction, where both languages are considered part of the entire school curriculum (Baker, 2011).

Several studies show that after-school classses may be an influential factor in HL maintenance (Hinton, 1999; Pak, 2003;Otcu, 2010; Shibata, 2000). The aim of after-school classes is to foster a positive inclusive identity and HL development among HL-speaking children (Otcu, 2010; Oriyama, 2010). Sometimes, immigrant parents believe that these educational settings can help them win an uphill battle for the preservation of their language and identity among their children (Brown, 2011; Octu, 2010). However, research shows that the role of HL after-school classes in this struggle might not always be straightforward. Brown's study of Korean HL students (2011) found that Korean HL weekend schools made no significant contribution to their HL maintenance. Furthermore, children may even develop negative attitudes toward community schools. A study of Chinese HL children in Canada (Li,2006) found that the children disliked their Chinese afterschool classes for their rigid and authoritative instructional methods that differ significantly from those used in formal Canadian education. Moreover, Li found that the teachers in these Chinese classes are often parent volunteers who do not necessarily have the skills and the knowledge to teach, and their lack of skill may have influenced the children's negative attitudes (Li, 2006). To recap, it appears that the impact of HL after-school classes on HL competence is not unambiguous and should be contextualized.

As for the formal bilingual education, several studies of bilingual preschools have shown its efficacy for HL acquisition and maintenance in comparison to monolingual educational settings (Gort \& Pontier, 2013; Méndez, Crais, Castro, \& Kainz, 2015; Bialystok, 2018). For example, in a study of bilingual Russian-Hebrew kindergartens by Schwartz (2014) preschool children were compared with those attending monolingual preschools on measures of paradigmatic and syntagmatic knowledge of vocabulary in HL (Russian) and the societal language (Hebrew). 
Whereas children from the bilingual preschool showed significant progress on vocabulary measures over time, those attending the monolingual Hebrew preschool showed a tendency for a lack of progress in HL. Another study (Schwartz \& Minkov, 2014), which focused on Israeli preschoolers' knowledge of Russian inflectional morphology, also indicated significant differences between the performance of children attending Hebrew monolingual kindergartens and those attending bilingual Russian-Hebrew kindergartens, in favor of bilingual education.

To sum up, prior research on language use at home and formal bilingual education as part of parents' FLP showed a significant contribution of these factors to HL children's lexical and grammatical knowledge of Russian (Oh \& Fuligini, 2007; Park \& Sarkar, 2007; Schwartz, 2008; Altman et al., 2014). However, until now the role of formal bilingual education has not been compared with the role played by community after-school HL classes. This study investigates the impact of Russian language use at home and in educational settings of both types on the acquisition of Russian noun morphology by Russian-speaking adolescents in Israel, the United States, Finland, and Germany. We measure HSs' language competence by the quantity and quality of errors in pronominal inflectional morphology in oral narratives. In the next section, we briefly describe the morphological features of Russian relevant to the present study.

\section{The Case System of Full ANd Heritage Russian}

The following description of the Russian case system is brief, reduced to the necessary minimum for the present study. Nearly every noun, every adjective, every numeral, and every pronoun has to be put in one of six different cases: Nominative, Genitive, Dative, Accusative, Instrumental, and Prepositional, marked by different, and sometimes homonymous, endings. The Russian case system includes multiple declensional distinctions, additional cases, $\stackrel{3}{-}$ and prepositional constructions (Belošapkova, 1989, Timberlake, 2004; Zaliznjak, 1977, 2002). The choice of the specific ending depends on the case and, if the noun is singular, on the declension type. Russian has three main types of inflection changes (declensions). ${ }^{4}$ Each declension is associated with the predominant grammatical gender, but there is no one-to-one correspondence between genders and declension types. The First Declension (hereafter DEC1) includes mostly feminine nouns and some masculine nouns that end in $-a$ or $-j a$, e.g., sumk- $a$ 'bag.' The same case endings apply for both genders. The vast majority of masculine nouns ending in a hard or soft consonant and all neuter nouns belong to the Second Declension (hereafter DEC2), e.g., stol- $\phi$ 'table.' The Third Declension (hereafter DEC3) includes only feminine nouns ending in a palatal consonant, e.g., sol' 'salt.'

Russian monolingual children acquire the basics of the nominal case system before age 3 (Gvozdev, 1961). Although the acquisition of irregular forms continues up to age 6, errors are restricted almost exclusively to assigning nouns to the wrong declension type. Regarding the choice of case in and of itself, monolingual Russian-speaking children can be seen as infallible from the very beginning of speech production (Ceytlin, 2009; Gvozdev, 1961; Protassova, 1997).

The reduction of the case system in heritage Russian has been investigated mostly in the context of English-Russian American bilinguals. Polinsky (2006, 2008) notes that in American Russian the case system has undergone reduction and simplification, with the Nominative case supplanting all oblique cases. Isurin \& Ivanova-Sullivan (2008) also describe patterns of interchanging 
between different oblique cases by HSs. Kopeliovich (2013) echoes Polinsky's findings and notes that the most common errors in case usage among Russian-Hebrew adolescents is the replacement of oblique cases by Nominative forms. Protassova, Mäki, \& Rodina (2017) investigated the acquisition of the case system by Finnish-Russian bilinguals and report that compared to their monolingual counterparts in Russia, Finnish-Russian bilinguals make more mistakes in case usage, and their errors are systemic and cannot be directly attributed to transfer from the dominant language. Common errors included the placement of the word stress, the absence of phonetic alternation in the word stem for some nouns, and the wrong choice of an ending. Although cases of the singular are acquired in the same sequence-the nominative, accusative, prepositional, genitive, dative, instrumental, by both Russian monolinguals and Russian-Finnish bilinguals, the pace of their acquisition of inflectional morphology is slower for the bilingual group. To the best of our knowledge, the reduction of the case system in heritage Russian among Russian-German speaking adolescents has not been investigated.

\section{The Gender System OF Full AND Heritage RuSSIAN}

Russian has three grammatical genders (masculine, feminine, and neuter), characterizing nouns, pronouns, adjectives, numerals, participles, and past-tense verbs. Feminine nouns typically end with the vowel $-a$ or with a palatalized consonant, masculine nouns - with a consonant, which may or may not be palatalized (zero-ending), and neuter nouns with a stressed and unstressed $-O$ and an unstressed $-e$; however, there are many exceptions to this rule.

Based on an analysis of children's production data, Ceytlin $(2005$; 2009) pointed out that monolingual Russian-speaking children first acquire nouns ending in $-a$, regardless of their gender, and masculine nouns with zero-ending. By the approximate age of 2;6 children seem to have acquired these basic elements of the Russian gender system. Although this intermediate system includes only two genders (masculine and feminine), gender agreement with such nouns seems error-free. The gender of neuter nouns ending in a stressed vowel is acquired between the ages of $3 ; 0$ and 4;0. Gender agreement of feminine nouns ending in a palatalized consonant, as well as the gender of stem-stressed (end-unstressed) neuter nouns (e.g., jablok-o, 'apple'), is acquired later, around the age of 6;0, since the gender of such nouns often cannot be identified in oral speech based on their formal or semantic characteristics.

Polinsky (2006) found that in American Russian (which she identifies as a dialect of Russian HS speakers in the United States) the three-part gender system is reanalyzed into a two-part system (feminine and masculine) with end-stressed neuter nouns retaining their gender, while the stemstressed neuter nouns and feminine nouns ending with palatalized consonants, in the absence of semantic hints, are usually treated as feminine or masculine. In an additional study of incomplete gender acquisition (2008), Polinsky found that the more proficient HSs were able to maintain the three-gender system, whereas those who were less proficient tended to reduce it to two genders.

\section{SOCIAL CONTEXT OF THE STUDY: RUSSIAN-SPEAKING IMMIGRANTS IN ISRAEL, THE UNITED STATES, Finland AND GERMANY}

Our research population includes Russian HSs residing in four host countries-Israel, the United States, Finland, and Germany. Between 1990 and 1999, over 835,000 people immigrated from the former Soviet Union to Israel (Gitelman, 2016). The large-scale character of this immigration together with a high demographic concentration in some areas of the country may explain this 
community's established practices of retaining Russian. However, in Israel the option to learn Russian as part of the mainstream curriculum is limited mainly to high schools No formal bilingual education has been established at the lower educational levels, and Russian is supported only by private bilingual preschools and after-school classes. In the United States, 600,000 Russianspeaking immigrants arrived between 1999 and 2016 (Yearbook of Immigration Statistics, 2016). In 2017, Russian was the primary spoken language at home for 907,362 Americans (U.S. Census Bureau, 2018). Like in Israel, in the United States, the maintenance of Russian as a HL is not part of mainstream educational policy. To the best of our knowledge,, only three Russian language immersion schools and four dual Russian-English immersion schools exist in the country (two of which are in New York) (the Center for Applied Linguistics, 2011). In Finland, out of a population of almost 5.5 million, more than 77,000 are Russian speakers (Statistics Finland, 2018). Over the last two decades, Russian speakers have become the largest immigrant linguistic minority, and Russian is taught as a HL in many mainstream schools, and a number of bilingual Finnish-Russian schools exist throughout the country. About 3,500,000 speakers of Russian live in Germany, according to the Russian Ministry of Foreign Affairs. About a third of this population are immigrants from the former Soviet Union. At the beginning of the 1990s, bilingual RussianGerman schools were established throughout the country. In addition, Russian is taught either as an obligatory or an optional foreign language in some German schools (Witzlack-Makarevich \& Wulff, 2017).

As can be seen from this description, the educational support for Russian as a HL in Germany and Finland is significantly different from that in Israel and the United States. These differences between Israel and the United States, on the one hand, and Germany and Finland, on the other, can be attributed to the differences in the status of Russian and its perceived instrumental value in these countries. Notably, in both Germany and Finland, Russian is valued as the language of a close or neighbouring country and as one of the most widely spoken European languages (Protassova, 2018).

\section{Participants}

This study involved adolescent HSs participants from four bilingual groups: Russian-Hebrew $(\mathrm{RH}, \mathrm{n}=11)$, Russian-English (RE, n=11), Russian-German (RG, n=9) and Russian-Finnish (RF, $\mathrm{n}=14$ ). The participants' age ranged between 13 to 17 years, and all of them were attending school in their respective countries. Most participants were born in the host country. Four participants were brought to the host country in early childhood: two in the Russian-Hebrew group (at ages 1;5 and 4) and two in the Russian-Finnish group (at ages 3 and 4). ${ }^{6}$ Most participants (39 out of 45) reported a relatively high level of parents' education (university degree). ${ }^{7}$ The participants had diverse educational experiences with heritage language maintenance and development (see Table 1). In a parallel study, which explored the identity of participants (Kagan et al., 2019), the adolescents displayed a variety of identities, most of them multiple and hybrid.

\section{Research Questions}

Drawing from the studies reviewed in the preceding sections, the present study addresses the following research questions: 
1. What types of errors in noun inflectional morphology do Russian-speaking heritage adolescents in the four participant groups make in oral speech production?

2. Are the four participant groups of Russian HSs similar or different in their knowledge of noun inflectional morphology in Russian?

3. What is the role of socio-linguistic factors, specifically the use of Russian at home, after school and in formal bilingual education, in the acquisition of noun inflectional morphology by Russian HSs?

\section{METHOD}

\section{Methodological Design}

The study used mixed methods research design, including a descriptive analysis of errors in noun production, and a comparative quantitative analysis. The first research question was explored with the help of qualitative analysis of errors. The second research question involved the use of quantitative comparisons between participant groups. Since to our best knowledge, there was no previous comparisons between the target research populations, we could not provide any predictions. The final question required the analysis of sociolinguistic data concerning Kagan's model of the HL support triad - family, community/community schools, and formal education. We predicted that there would be a link between Russian use at home and the type of bilingual education, as independent variables, and the participants' competence in Russian noun inflectional morphology as a dependent variable.

\section{Research Instrument and Procedure \\ Frog Story}

The participants were given the children's picture book, Frog, Where Are You? by Mayer and Mayer (1978) as a prompt for narration and were asked to tell a story based on the events that unfolded with each picture. Participants were interviewed individually for 45 minutes. Each participant told a story based on the pictures. Since our aim was to detect morphosynactic features in unprepared speech, we followed the methodology used by Isurin (2008) and instructed our participants not to look through the book prior to telling the story. The participants were asked to tell the story while looking at the pictures. The narrations were audio-recorded, transcribed, and analyzed qualitatively and quantitatively.

\section{Sociolinguistic Background Questionnaire}

The participants were asked to fill in a background questionnaire prior to the study with the aim of gathering sociolinguistic information (age, gender, place of birth, parental education), selfevaluated language use at home and with friends, and participants' educational experience (formal versus informal) in the heritage language. We assigned one point for each answer. The questionnaire was presented in the host country's language (see Appendix 1).

\section{Results}

\section{Research Question \#1: Qualitative Analysis}

We used qualitative data analysis to identify types of errors in the two target categories of case and gender agreement. Table 1 presents raw numbers and the percentage of ]errors in case and gender. 
In the lines specifying the subtypes of the errors, the percentage of the errors of the given subtype out of all the errors in the subsequent type (case / gender errors) is given in brackets.

\section{Table 1.}

Error Types and Frequencies.

\begin{tabular}{|c|c|c|c|c|}
\hline & $\mathrm{RH}$ & $\mathrm{RE}$ & $\mathrm{RF}$ & $\mathrm{RG}$ \\
\hline $\begin{array}{l}\text { The total number of nouns produced by the } \\
\text { speakers }\end{array}$ & 853 & 1198 & 1401 & 931 \\
\hline Case errors, occurrences & 41 & 88 & 9 & 4 \\
\hline Percent of case errors in the total of nouns & $4.80 \%$ & $7.34 \%$ & $0.64 \%$ & $0.43 \%$ \\
\hline $\begin{array}{l}\text { Substitutions of oblique case by Nominative } \\
\text { form }\end{array}$ & $\begin{array}{l}28 \\
(68.29 \%)\end{array}$ & $\begin{array}{l}62 \\
(70.45 \%)\end{array}$ & $1(11.11 \%)$ & $2(50 \%)$ \\
\hline Use of the wrong oblique case & $6(14.63 \%)$ & $\begin{array}{l}10 \\
(11.36 \%)\end{array}$ & $0(0 \%)$ & $2(50 \%)$ \\
\hline Mixing of cases for location and direction & $3(7.32 \%)$ & $\begin{array}{l}10 \\
(11.36 \%)\end{array}$ & $1(11.11 \%)$ & $0(0 \%)$ \\
\hline Gender errors, occurrences & 21 & 44 & 4 & 6 \\
\hline Percent gender errors in the total of nouns & $2.46 \%$ & $3.67 \%$ & $0.29 \%$ & $0.64 \%$ \\
\hline Noun-pronoun agreement errors & $\begin{array}{l}13 \\
(61.90 \%)\end{array}$ & $\begin{array}{l}17 \\
(38.64 \%)\end{array}$ & $3(75 \%)$ & $3(50 \%)$ \\
\hline Noun-verb agreement errors & $2(9.52 \%)$ & $\begin{array}{l}10 \\
(22.73 \%)\end{array}$ & $1(25 \%)$ & $1(16.67 \%)$ \\
\hline Noun-adjective agreement errors & $3(14.29 \%)$ & $6(13.64 \%)$ & $0(0 \%)$ & $1(16.67 \%)$ \\
\hline Erroneous gender/declension assignment & $3(14.29 \%)$ & $5(11.36 \%)$ & $0(0 \%)$ & $1(16.67 \%)$ \\
\hline
\end{tabular}

Substitution of Oblique Case by Nominative Form

In line with previous research on Russian-speaking bilingual adults and children (Polinsky, 2006, 2008; Schwartz \& Minkov, 2014), our data revealed that the main type of case error was the substitution of an oblique case by the Nominative form. The errors of this type accounted for $68 \%$, $70 \%, 11 \%$, and $50 \%$ of the total of case errors in the speech production of RH, RE, RF, and RG groups, respectively.

(1) \# Vidyat mal'čik i sobačka

(They) see the boy:NOM and the dog:NOM

(Correct: Vidjat mal'čika:ACC i sobačku:ACC)

\section{RE speaker}

(2) \# Sova s'el ljaguška

The owl:NOM ate:MASC the frog:NOM

(Correct: Sova:NOM s'ela:FEM ljagušku:ACC)

RE speaker 
(3) \# Vižu malen'kij čelovek

(I) see a little:NOM man:NOM

(Correct: Vižu malen'kogo:ACC čeloveka:ACC )

RH speaker

It is noteworthy that this error type occurred in the $\mathrm{RH}$ and $\mathrm{RE}$ groups in the majority of cases. At the same time, we found only three cases of substitution of an oblique case by the Nominative among the RG and RF groups.

Incorrect Use of Oblique Cases

The oblique cases could be replaced by another, erroneous oblique case:

(4) \# I pčoly načali za sobaku, i mal'čik upal.

And the bees set off after the dog:ACC, and the boy fell.

(Correct case, but still ignoring Russian syntax: I pčoly načali za sobakoj:INSTR, i mal'čik upal).

RH speaker

(5) \# On idjot k mal'čika.

$\mathrm{He}$ is going to the boy:GEN.

(Correct: * On idjot k mal'čiku:DAT).

RH speaker

Location-direction Case Mixing

The use of incorrect oblique case reveals the tendency for location/direction mixing, i.e., the use of the Accusative case, identifying direction, instead of the contextually correct Prepositional case, identifying location, and vice versa, e.g.:

(6) \# Mal'čik iščet $v$ derevo.

The boy is looking in the tree:ACC/NOM

(Correct: Mal'čik iščet $v$ dereve:PREP)

RH speaker

(7) \# Mal'čik i sobačka upali v reke.

The boy and the dog fell into the river:PREP

(Correct: Mal'čik i sobačka upali v reku:ACC)

RE speaker

(8) \# Est' luna na ulicu.

There is a moon on the street:ACC

(Correct, still atypical for Russian syntax: Est' luna na ulice:PREP)

RE speaker 
(9) \# Oni tut $v$ gnezde poleteli.

Here they flewinto the nest:PREP

(Correct: Oni tut v gnezdo:ACC poleteli)

RF speaker

Similar to the substitution of oblique cases by the Nominative form, in all cases but one this pattern of error was observed in the RH and RE groups, but not in the RG or RF participants.

\section{Errors in Gender Assignment and Gender Agreement}

Errors in gender assignment and gender agreement were found in a variety of grammatical constructions: (1) noun-pronoun agreement, including erroneous agreement with the pronoun kotoryj ("who," "that," "which") in subordinate clauses; (2) noun-adjective agreement; (3) nounverb agreement in the past tense, and (4) the use of erroneous declension.

\section{Noun-pronoun Agreement}

This was the most frequent type of erroneous gender agreement. The errors of this type accounted for $62 \%$ of of the RH group, $39 \%$ of the RE group, $75 \%$ of the RF group, and $50 \%$ of the RG group.

The errors of this type occurred mostly in the RH and RE groups, but also were found in the RG and RF groups.

(10) \# Vot eta zverjuška kotoryj idjot pod zemlju.

Here is that:FEM animal:FEM/DIM which:MASC goes under the ground.

(Correct: Vot eta zverjuška:FEM kotoraja:FEM idjot pod zemlju.)

\section{RH speaker}

(11) \# Etot životnyj kak ona nazyvajetsja?

This:MASC animal:MASC what is it:FEM called?

(Correct: Eto:NEUT životnoe:NEUT kak ono:NEUT name nazyvajetsja?)

RH speaker

(12) \# Tut sidit ljaguška etot.

Here sits frog:FEM this:MASC.

(Correct: Tut sidit ljaguška:FEM eta:FEM. )

RE speaker

(13) \# Etot ptica letit na nego.

This:MASC bird:FEM flies on him.

(Correct: Eta:FEM ptica:FEM letit na nego.)

RF speaker

\section{Noun-verb Agreement}

This type of error was found mainly among the RH and RE groups. We found only one occurrence in each of the RG and RF groups. 
(14) \# Sobaka upal i razbil banku.

The dog:FEM fell:MASC and broke:MASC the jar.

(Correct: Sobaka:FEM upala:FEM i razbila:FEM banku.)

\section{RE speaker}

(15) \# Vyšla ne znaju kak on nazyvajetsja

came out:FEM I don't know what is he :MASC named/called

(Correct: vyšel:MASC ne znaju kak on:MASC nazyvajetsja)

RH speaker

(16) \# Kogda on vstajot, sobaka zalezal na ego golovu.

When he gets up the dog:FEM climbed:MASC on his head.

(Correct: Kogda on vstal, sobaka:FEM zalezla:FEM na ego golovu.)

\section{RG speaker}

Ulej upala.

The beehive:MASC fell:FEM

(Correct: Ulej:MASC upal:MASC)

RF speaker

\section{Noun-adjective Agreement}

This type of erroneous gender agreement was relatively rare (see Table 1). Notably, we found only three occurrences of the erroneous noun-adjective agreement, all of them in the RE group:

(18) \# Mama, papa, ljaguški, braty, sestry, - oj, očen' bol’šoj sem'ja.

Mother, father, frogs, brothers, sisters - oh, very big:MASC family:FEM

(Correct: Mama, papa, ljaguški, brat'ja, sestry, oj, očen' bol’šaja:FEM semja:FEM)

\section{RE speaker}

(19) \# Ja dumaju, oni zabrali malen'kij ljagušku

I think they took a little:MASC:NOM frog:FEM:ACC

(Correct: Ja dumaju, oni zabrali malen'kuju:FEM:ACC ljagušku:FEM:ACC)

\section{RE speaker}

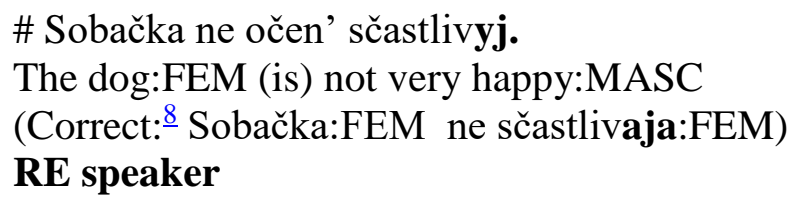

\section{Erroneous Gender/Declension Assignment}

In this type of error, the wrong gender was assigned to nouns, e.g., *eto ulje (this beehive, neuter form) instead of etot ulej (masculine form), but differently from the already described agreement error, this type of mistake often led to the use of the wrong declension, For example, feminine nouns of the DEC1 were declined according to the masculine DEC2, and vice versa. Erroneous 
declension categorization caused distortion of the noun ending, which was assigned according to the presumed gender. For example, in the Instrumental case, the ending -ej/-oj is used for DEC1 (usually feminine nouns), and the ending -em/-om for DEC2 (masculine nouns). In the following example, the ending - ej was attached to the masculine noun kamen' (stone) instead of the proper ending - em:

\# Sobaka tože iščet pod kamnej.

The dog is also looking under the stone:INST:DEC1

(Correct: Sobaka tože iščet pod kamnem:INST:DEC2)

\section{RH speaker}

In Example (22), the ending -om was attached to the feminine noun ljaguška (frog) instead of the proper ending -oj:

* Eto mal'čik s ljaguškom i sobačka.

This is a boy with a frog:INST:DEC2 and a dog.

(Correct: Eto mal'čik s ljaguškoj:INST:DEC1 i sobačka.)

RH speaker

In sum, as illustrated above, although errors of case and gender could be found in all four bilingual groups, the majority were found in the RE and RH groups. In addition, different types and subtypes of errors were made with different frequency: substitutions of oblique cases by the Nominative form and erroneous noun-pronoun gender agreement were the most common errors, while placedirection case mixing, erroneous noun-verb and noun-adjective agreement, and erroneous gender/declension assignment occurred more rarely.

\section{Within-group Qualitative Analysis}

In the following section, we will present the proportions of case and gender errors in the total number of nouns produced by each participant per group. We decided to report the proportions rather than raw scores due to differences in the length of the produced narratives between the participants.

\section{Figure 1. Russian-Hebrew Group: Percentage of Erroneous Forms out of} Total Number of Nouns in HR Participants' Narratives

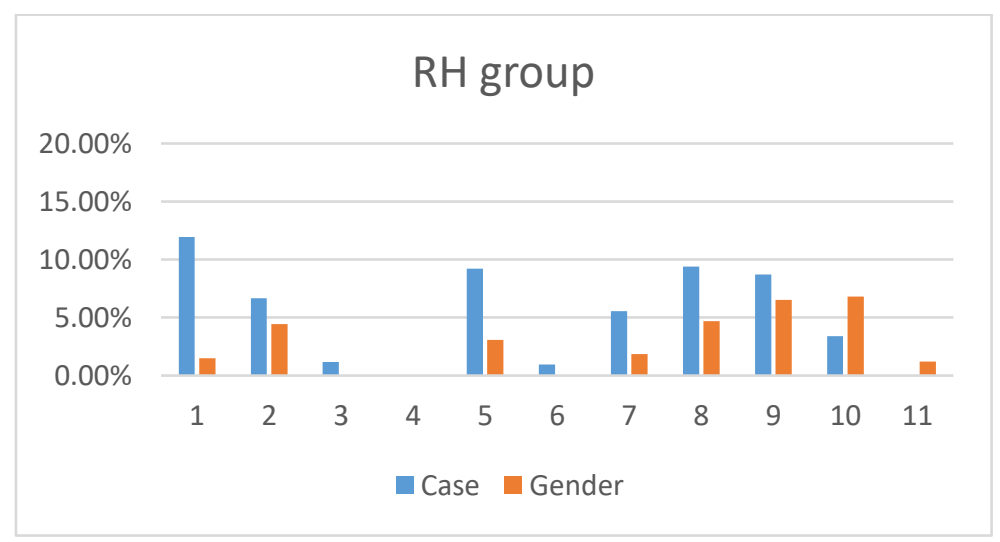


As the graph shows, most participants produced both categories of errors in their speech. The proportions of both types of errors varied widely $(0 \%$ to $11.94 \%$ for case and $0 \%$ to $6.82 \%$ for gender). Four children out of 11 produced no or very few errors. In addition, it is noteworthy that all RH participants except one made more case errors than gender errors. Thus, it appeares that the case category is more challenging for this group than the gender category.

Figure 2. Russian-English Group: Percentage of Erroneous Forms out of Total Number of Nouns in the Narratives of the RE Participants

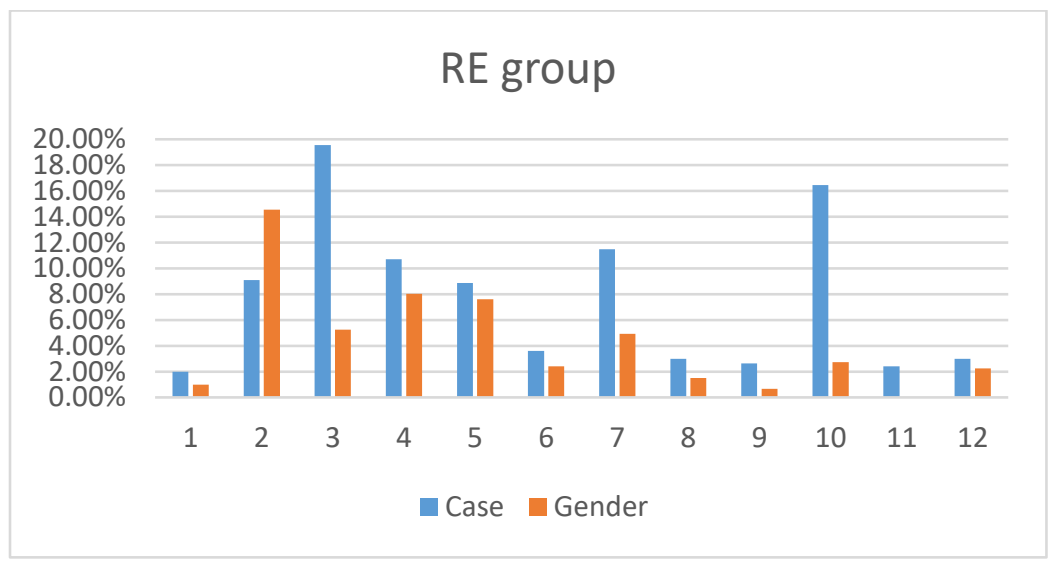

The figure shows that, similarly to the RH group, all RE participants except one produced both types of errors, i.e., case and gender agreement were challenging for this group. Similarly to the $\mathrm{RH}$ participants, in the RE group, the proportion of both types of errors varied widely (from $2 \%$ to $19.55 \%$ for case and from $0 \%$ to $14.55 \%$ for gender).

Figure 3. Russian-German Group: Percentage of Erroneous Forms out of the Total Number of Nouns in the RG Participant Narratives

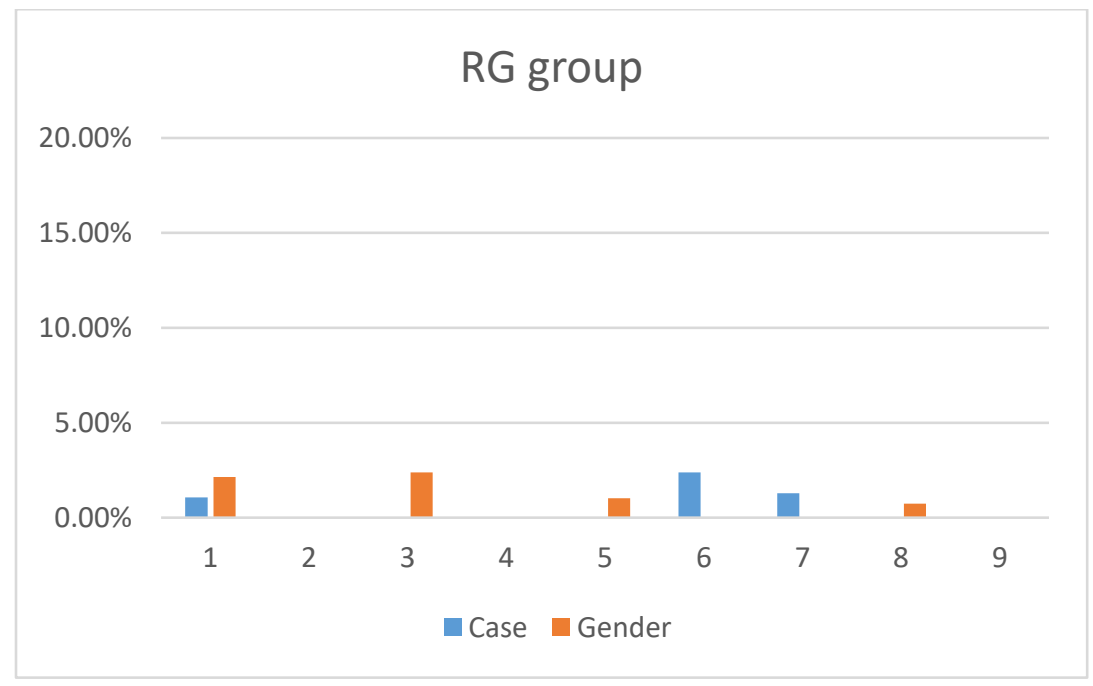


The percentage of errors in both categories was very low in this group. In contrast to the RH and the RE groups, case choice was not more challenging for the RG participants than gender agreement. In addition, unlike RH and RE participants, the RG group showed greater homogeneity: Only one participant made both types of errors, and the speech of three participants was free of errors. 
Figure 4. Russian-Finnish Group: Percentage of Erroneous Forms out of the Total Number of Nouns in the RF Participant Narratives Group

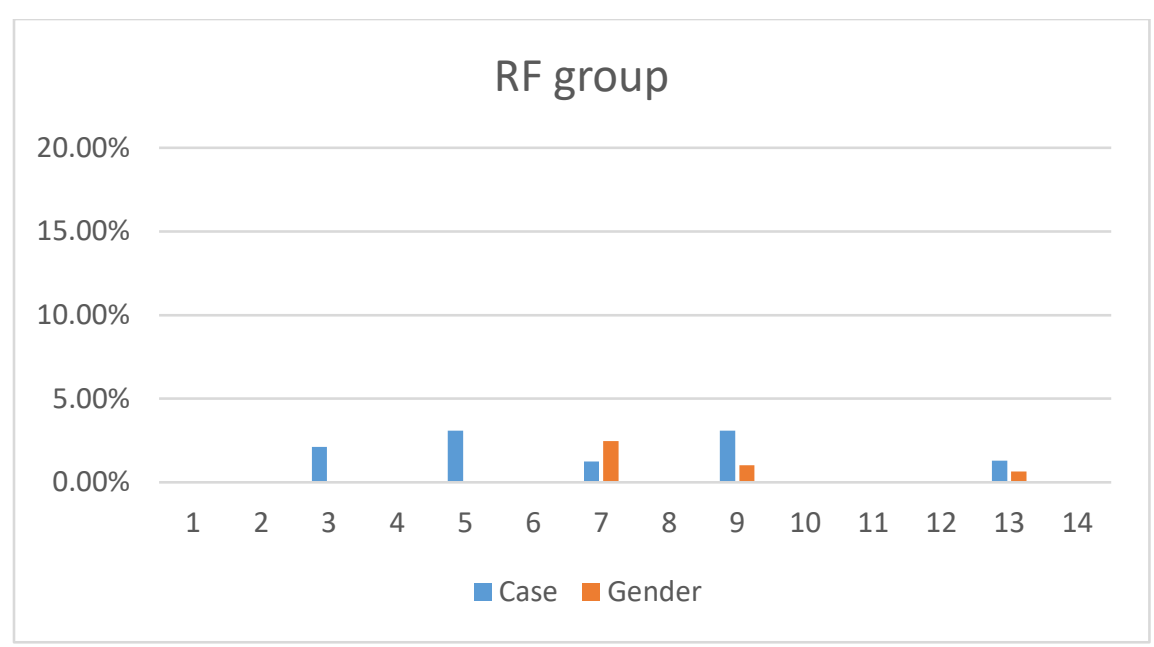

It can be seen from the graph that, similarly to the RG participants, the proportion of errors in the RF group was very low, and these participants' production was very homogenous. No participant produced more than $3 \%$ of errors on case and gender; the speech of nine out of 14 participants was free of errors in case choice and gender agreement. Only three participants made gender errors. Also noteworthy is that, similarly to the RH and the RE participants, this group found case choice more difficult than gender agreement.

\section{QUANTITATIVE ReSUlts}

Quantitative results are presented in the following two sections: (1) between-group analysis and (2) within-group analysis.

\section{Section 1: Between-group Analysis}

First, we will present the results of the comparison between the groups on the bio-social (age and gender) and socio-linguistic variables (home language use with parents and friends ${ }^{9}$ and type of bilingual education). Next, we will compare the groups on different variables of inflectional morphology production by applying the Chi-Square, Kruskal-Wallis analysis for nonparametric comparisons, followed up with post hoc analyses.

Three variables were dummy-coded: gender, Russian use at home, and bilingual education. Thus, participants were contrasted on gender, bilingual education (those who were educated in bilingual schools versus those who were not educated in bilingual schools), and home language use (those whose families used mixed L1 and L2 ${ }^{10}$ versus those who used only Russian).

Nonparametric Comparisons between Groups on Bio-social and Socio-linguistic Variables Table 2 presents the background data for the bio-social variables, home language use with parents and friends, and type of bilingual education (formal versus informal) and results of the statistical comparison tests. To examine differences between the groups on gender, home language use and 
type of bilingual education, we used the Chi-Square nonparametric test, and for the age variable, we used the Kruskal-Wallis nonparametric analysis.

Table 2.

Bio-social and Socio-Linguistic Variables: Data and Comparisons

\begin{tabular}{|l|c|c|c|c|c|}
\hline Variables & $\begin{array}{c}\text { RH } \\
(\mathbf{n = 1 1})\end{array}$ & $\begin{array}{c}\text { RE } \\
(\mathbf{n = 1 1})\end{array}$ & $\begin{array}{c}\text { RG } \\
(\mathbf{n = 9})\end{array}$ & $\begin{array}{c}\mathbf{R F} \\
(\mathbf{n = 1 4})\end{array}$ & $\chi^{\mathbf{2}}$ \\
\hline $\begin{array}{l}\text { Age in years }(M(S D)) \\
\text { Age range }\end{array}$ & $\begin{array}{c}15.36(0.92) \\
16-17\end{array}$ & $\begin{array}{c}15.18(1.47) \\
13-17\end{array}$ & $\begin{array}{c}15.22 \\
(1.53) \\
13-17\end{array}$ & $\begin{array}{c}16.14 \\
(0.86) \\
15-17\end{array}$ & 3.91 \\
\hline Gender (boys: girls) & $5: 6$ & $3: 8$ & $2: 7$ & $5: 9$ & $5.00^{*}$ \\
\hline RHL use at home & 6 & 3 & 0 & 0 & $17.20^{* * *}$ \\
\hline $\begin{array}{l}\text { Parents, child use mixed } \\
\text { Russian and host country } \\
\text { language (no. of participants) }\end{array}$ & 4 & 3 & 0 & 0 & \\
\hline $\begin{array}{l}\text { Parents' use of Russian only/ } \\
\text { child's mixed use of both } \\
\text { languages (no. of participants) }\end{array}$ & 1 & 5 & 9 & 14 & \\
\hline $\begin{array}{l}\text { Only Russian use at home (no. } \\
\text { of participants) }\end{array}$ & 5 & 4 & 8 & 14 & $15.84^{* * *}$ \\
\hline $\begin{array}{l}\text { RHL use with friends (no. of } \\
\text { participants) }\end{array}$ & 11 & 11 & 4 & 3 & $3.76^{*}$ \\
\hline Bilingual Education & 0 & 0 & 5 & 11 & \\
\hline $\begin{array}{l}\text { After-school classes (no. of } \\
\text { participants) }\end{array}$ & & & & & \\
\hline $\begin{array}{l}\text { Formal bilingual schooling } \\
\text { (number of participants) }\end{array}$ & & & & & \\
\hline
\end{tabular}

$\mathrm{RG}=$ Russian-German-speaking teenagers

$\mathrm{RE}=$ Russian-English speaking teenagers

$\mathrm{RF}=$ Russian-Finnish-speaking teenagers

RHL $=$ Russian Heritage Language

Notes: $* \mathrm{p}<.05, * * * \mathrm{p}<.001$

Notes: $* \mathrm{p}<.05, * * * \mathrm{p}<.001$

The statistical comparison tests revealed significant differences among the groups on all variables except for age : gender, $\chi^{2}(1,3, N=45)=5.00, p=.02$, Russian use at home $\chi^{2}(2, N=45)=$ $17.20, p=.00)$, Russian use with friends $\chi^{2}(1,3, N=45)=15.84, p=.05$, and type of bilingual education $\chi^{2}(1,3, N=45)=3.76, p=.05$. As the table shows, the RG- and RF-speaking adolescents reported exclusively Russian use at home with only sporadic language mixing. In addition, only these two groups reported attending formal bilingual schooling in Russian. Finally, all RF-speaking adolescents and all but one RG-speaking adolescents reported using the HL with friends. 
Since we found significant differences among the four groups on the gender variable, it was necessary to control for the relationship between the gender variable and the dependent variables. Thus, we ran a correlation analysis between gender and the variable of noun inflectional morphology competence for the entire sample. The results showed no significant correlations between the target variables.

\section{Nonparametric Comparisons between the Groups on the Dependent Variables}

We performed a nonparametric one-way ANOVA analysis of variance using Wilcoxon (KruskalWallis) followed up by post hoc comparisons. Significant differences between the groups are indicated by means of Latin letters $\left({ }^{a}, b\right)$, with different letters indicating a statistically significant difference; groups sharing a common superscript did not differ significantly.

Table 3 presents group comparisons on competence in gender assignment and case choice. The measures of gender and case errors were constructed by calculating the percentage of case/gender errors in the total number of nouns produced by participants.

Table 3.

Means and Standard Deviations of the Constructed Measure of Noun Inflectional Morphology for Gender and Case Errors in Narrative Production

\begin{tabular}{|llllcccccc|}
\hline Variables & $\begin{array}{l}\text { RH } \\
(\mathbf{n = 1 1})\end{array}$ & & $\begin{array}{l}\text { RE } \\
(\mathbf{n = 1 1})\end{array}$ & $\begin{array}{l}\text { RG } \\
(\mathbf{n = 9})\end{array}$ & $\begin{array}{l}\text { RF } \\
(\mathbf{n = 1 4})\end{array}$ & $\chi^{\mathbf{2}}$ \\
\hline & $M$ & $S D$ & $M$ & $S D$ & $M$ & $S D$ & $M$ & $S D$ & \\
\hline $\begin{array}{l}\text { Gender errors } \\
\text { (in \%) }\end{array}$ & $2.73^{\mathrm{b}}$ & 2.55 & $4.42^{\mathrm{b}}$ & 4.33 & $0.70^{\mathrm{a}}$ & 0.97 & $0.30^{\mathrm{a}}$ & 0.70 & $17.57^{* * *}$ \\
Case errors (in \%) & $5.18^{\mathrm{b}}$ & 4.31 & $8.10^{\mathrm{b}}$ & 6.05 & $0.53^{\mathrm{a}}$ & 0.86 & $0.77^{\mathrm{a}}$ & 1.19 & $22.71^{* * *}$ \\
\hline
\end{tabular}

Notes: $p<.001$

It is evident that the RH and RE groups as well as the RG and the RF groups did not differ significantly from one another on the target measures. At the same time, post hoc comparisons revealed that the RG and RF groups significantly outperformed the RH and RE groups on both gender and case measures: gender measure $-F(3,41)=6.48, p<0.001$; and case measure $-F(3$, $41)=10.76, p<0.001)$. This means that the RG and the RFparticipants produced significantly fewer case and gender errors then the RH and the REparticipants.

\section{DISCUSSION}

Regarding the first research question, on the types of errors made by participants in nominal inflectional morphology, we found that all four target groups produced errors in case and gender. On the second research question, comparing the groups' performance, they differed significantly on their knowledge of Russian noun inflectional morphology and the majority of errors were found in the RE and RH groups. Finally, as predicted in the third research question, we found a statistically strong correlation between Russian use at home and the type of bilingual education participants attended with and their competence in the noun inflectional morphology in Russian. In the following sections we will elaborate on these findings addressing each question separately. 


\section{Types of Noun Production Errors in Russian}

The results of the analysis showed that participants in all four groups made the same types of errors (e.g., substitutions of oblique cases by the Nominative form, noun-pronoun and noun-verb agreement errors). For most participants case choice was more challenging than gender agreement. Certain types of errors, such as noun-adjective agreement, erroneous gender assignment, and use of the wrong oblique case, were found almost exclusively in the RH and the RE groups. Finally, the types of errors per se did not differ from those described in the previous research on Russian morphology among bilingual adolescents and adults (Polinsky, 2006, 2008; Isurin \& IvanovaSullivan, 2008; Kopeliovich, 2013; Protassova, Mäki, \& Rodina 2017).

\section{Comparison between Groups on the Noun Inflectional Morphology}

Although all Russian HSs in this study produced errors in case and gender, the groups differed significantly inn frequency of these errors. In particular, the RG- and RF-groups produced significantly fewer case and gender errors than the RH- and RF-groups. A closer examination reveals that the participants from the groups with high error rates, i.e., the RE- and RH-speakers, showed wider intra-group differences than the RG and RF groups. Whereas all the RG and RF participants made remarkably few errors of case and gender, the RE- and RH-speakers exhibited wide variation in their control of these morphological features. Since the RE and RH participants did not report formal bilingual education, their within-group heterogeneity could be arguably attributed to the different patterns of Russian use at home. This assumption is supported by the fact that a closer look at the few RE- and RH-speaking adolescents, who produced the lowest proportions of morphological errors, revealed that they reportedly use Russian at home exclusively or that their parents adhere to the use of Russian without code-switching.

This pattern of data can be interpreted within the theoretical model of the HL proficiency continuum suggested by Polinsky and Kagan (2007). This interpretation places the four groups of Russian HSs on two ends of the continuum comprising two clusters: the RH and RE groups are positioned at the lower-level cluster as their performance exhibits characteristics of the basilectal speakers. At the same time, the RG and RF groups comprised the higher-level cluster as they performed similarly to the acrolectal speakers at the opposite end of the continuum (Polinsky \& Kagan, 2007).

\section{The Role of Russian Use at Home and Formal Bilingual Education in Russian HL Acquisition}

Drawing on Kagan's (2005) triad model: family - community/community schools - formal education, we found significant differences between the groups on the socio-linguistic background factors. The high-performing speakers in the RG and RF groups reported predominantly Russian use at home without any language mixing and had received formal bilingual schooling in Russian. In contrast, only six out of the 22 participants in the RE and the RH groups combined reported using exclusively Russian at home, and none of these participants had received formal bilingual schooling although many of them had participated in after-school programs. We can, therefore, conclude that the type of the educational setting (formal bilingual education vs. community schools) and the use of Russian at home can be considered as influential factors in the development of Russian noun inflectional morphology among HSs. 
Furthermore, it can be hypothesized that the use of Russian at home and the educational settings are interrelated: on the one hand, parents who attach great importance to the preservation of the heritage language and insist on maintaining this language in home communications are more likely to send their child to bilingual education settings (Schwartz et al., 2010). On the other hand, one might assume that in cases where the home language (Russian) is intensively supported by formal bilingual education, the children are less likely to resist the family policy of Russian-only at home. However, we acknowledge that the nature of this relationship cannot be discussed without addressing the availability of formal bilingual education in the host countries. In Israel and the U.S., formal bilingual education with Russian as one of the languages is much less accessible than in both Finland and Germany which, being part by the European educational philosophy and law, promote bilingual education and multilingual policies in general.

\section{LIMITATIONS OF THE STUDY AND CONCLUSIONS}

The present study examined the knowledge of Russian noun inflectional morphology among Russian HSs from four different linguistic environments and with different socio-linguistic backgrounds, defined by the use of Russian at home, and different types of educational settings (after-school programs and formal bilingual education). This study contributes to our understanding of the nature and types of errors in Russian noun morphology among Russian HSs. Although all participants in the study produced the same types of errors, the frequency of errors differed significantly among the groups. These differences can be partially attributed to such sociolinguistic factors as language use at home and type of bilingual education. However, the study did not examine the possible role of linguistic proximity between the participants' L2 (Hebrew, English, Finnish and German) and Russian as a HL. Future research is needed to examine this question.

The study stresses that an examination of socio-linguistic factors influencing HSs knowledge should be contextualized within macro-perspectives, such as state or national language policy and language educational policies, as well as within micro-perspectives, such as community and family language policy. Future research focusing on other major ethno-linguistic immigrant communities in the world such as the Turkish-speaking and Mandarin-speaking communities, should take into account these perspectives. Future studies are also encouraged to provide future empirical support the two theoretical models examined in a novel way here: Kagan's (2005) triad model of HL support: family - community/community schools - formal education, and the continuum of heritage language proficiency (Polinsky and Kagan, 2007).

\section{REFERENCES}

Altman, C., Burstein Feldman, Z., Yitzhaki, D., Armon Lotem, S., \& Walters, J. (2014). Family language policies, reported language use and proficiency in Russian-Hebrew bilingual children in Israel. Journal of Multilingual and Multicultural Development, 35(3), 216-234.

BAMF (2015). Bundesamt für Migration und Flüchtlinge [Federal Office for Migration and Refugees]. Migrationsbericht 2015 [Migration report 2015]. Retrieved from www.bamf.de/SharedDocs/Anlagen/DE/Publikationen/Migrationsberichte/migrationsbericht2015.pdf

Baker, C. (2011). Foundations of bilingual education and bilingualism (Vol. 79). Multilingual matters. 
Belošapkova, Vera A. (1989) Imja suščestvitel'noe. [The noun]. In Vera A. Belošapkova, V., Bryzgunova, E. A., \& Zemskaja, E. (Eds), Sovremennyj russkij jazyk. Moscow, Russia: Vysšaja škola, 402-42.

Ben-Rafael, E., Lyubansky, M., Glöckner, O., Harris, P., Israel, Y., Jasper, W., \& Schoeps, J. (2006). Building a diaspora: Russian Jews in Israel, Germany and the USA. Leiden, The Netherlands: Brill.

Brown, C. L. (2011). Maintaining heritage language: Perspectives of Korean parents. Multicultural Education, 19(1), 31.

Bialystok, E. (2018). Bilingual education for young children: review of the effects and consequences. International journal of bilingual education and bilingualism, 21(6), 666-679.

Caldas, S., \& Caron-Caldas, S. (2000). The influence of family, school, and community on bilingual preference: Results from a Louisiana/Quebec case study. Journal of Applied Psycholinguistics, 21 (3), 365-381.

Carreira, M., \& Kagan, O. (2011). The results of the National Heritage Language Survey: Implications for teaching, curriculum design, and professional development. Foreign Language Annals, 44(1), 40-64.

Center for Applied Linguistics. Annual Reports, 2011-2017. Retrieved August 06, 2018, from http://www.cal.org/who-we-are/annual-reports

Ceytlin, S.N. (2005) "Kategorija roda v detskoj reči” [The category of gender in children's speech.]. In: A.V. Bondarko at al. (Eds.), Problemy funkcionalnoj grammatiki [Problems of functional grammar]. St Petersburg, Russia: Rossijskaja Akademija Nauk, 346-375.

Ceytlin, S.N. (2009) Ocherki po slovoobrazovaniju I formoobrazovaniju v detskoj reči [Articles on word formation in children's speech]. Moscow, Russia: Znak.

De Statis: Statistisches Bundesamt [Federal Statistical Office (Germany)].(n.d.) Persons with a migrant background. Population, 2012, by migrant status and citizenship. Retrieved from https://www.destatis.de/EN/FactsFigures/SocietyState/Population/MigrationIntegration/Perso nsMigrationBackground/Tables/MigrantStatusFormerCitizenhip.html

Fishman, J. A. (1991). Reversing language shift: Theoretical and empirical foundations of assistance to threatened languages. Clevedon, UK: Multilingual Matters.

Fishman, J. (2001). 300-Plus years of heritage language education. In Peyton, J., Ranard, D. A., \& McGinnis, S. (Eds.), Heritage languages in America: Preserving a national resource language in education. (pp. 87-97). McHenry, IL: Delta Systems Co., Inc./Washington, DC: Center for Applied Linguistics

Fishman, J.A. (Ed.) (2001). Can threatened languages be saved? Reversing language shift, revisited. Clevedon, UK: Multilingual Matters.

Garcia, O., Zakharia, Z., \& Otcu, B. (2013). Bilingual community education: Beyond heritage language education and bilingual education in New York. Bilingual community education and multilingualism, 3-44.

Gitelman, Z. (Ed.). (2016). The New Jewish Diaspora: Russian-Speaking Immigrants in the United States, Israel, and Germany. New Brunswick, New Jersey; London: Rutgers University Press. Retrieved from http://www.jstor.org/stable/j.ctt1ch7904

Grin, F. (2003). Language policy evaluation and the European Charter for Regional or Minority Languages. London, UK: Palgrave Macmillan.

Gvozdev, A.N. (1961). Voprosy izuchenija detskoj rechi [Questions of the study of child speech]. Moscow, Russia: Izdatel'stvo APN RSFSR. 
Gort, M., \& Pontier, R. W. (2013). Exploring bilingual pedagogies in dual language preschool classrooms. Language and Education, 27(3), 223-245.

Harris, J. R. (1995). Where is the child's environment? A group socialization theory of development. Psychological Review, 103(3), 458-489.

Hinton, L. (1999). Trading tongues: Loss of heritage languages in the United States. English Today, 15(4), 21-30.

Isurin, L. 2005. Cross linguistic transfer in word order: Evidence from L1 forgetting and L2 acquisition. In: Cohen, J., McAlister, K.T., Rolstad, K., \& MacSwan, J. (Eds.) ISB4: Proceedings of the International Symposium on Bilingualism, pp. 1115-1130. Somerville, MA: Cascadilla Press.

Isurin, L. (2011). Russian diaspora: Culture, identity, and language change. Berlin, Germany: Walter de Gruyter.

Isurin, L., \& Ivanova-Sullivan, T. (2008). Lost in between: The case of Russian heritage speakers. Heritage Language Journal, 6(1), 72-104. Available from http://www.heritagelanguages.org

Isurin, L, \& Riehl, C.M. (2017). Introduction. In: Isurin, L., \& Riehl, C.M. (Eds.) Integration, identity and language maintenance in young immigrants. Russian Germans or German Russians. Amsterdam, The Netherlands/Philadelphia, PA: John Benjamins.

Kagan, O. (2017). Academic Writing Proficiency of Russian Heritage Speakers. In: Brinton, D., Kagan, O. \& Bauckus, S. (Eds.) Heritage language education: A new field emerging (pp. 181198). New York, NY: Routledge.

Kagan, O. (2005). In support of a proficiency-based definition of heritage language learners: The case of Russian. International journal of bilingual education and bilingualism, 8(2-3), 213221.

Kagan, O., Minkov, M., Protassova, E., \& Schwartz, M. (2019). Osobennosti russkogo jazyka u mnogojazyčnyx podrostkov v Germanii, Israile, USA i Finlandii. In Mnogojazychie i obrazovanie (pp. 49-60). Retorika.

Kamynin, Mikhail (28 May 2007). "Russian MFA Spokesman Mikhail Kamynin interview with RIA Novosti regarding upcoming conference on status of Russian Language Abroad". Ministry of Foreign Affairs of the Russian Federation. Retrieved from http://www.mid.ru/ bdomp/brp_4.nsf/e78a48070f128a7b43256999005bcbb3/55cec39404735aadc32572ea005b9 953!OpenDocument

Kopeliovich, S. (2013). Happylingual: A family project for enhancing and balancing multilingual development. In Successful family language policy (pp. 249-275). Dordrecht, The Netherlands: Springer.

Kagan, O., Minkov,M., Protassova, E., \& Schwartz, M. (manuscript in preparation). Identity of adolescent heritage speakers of Russian in the U.S., Israel, Germany and Finland: A comparison of socio-linguistic features.

Lewis, M.P., Simons, G.F., \& Fennig, C.D. (Eds.). 2014. Ethnologue: Languages of the world (17 ed.) Dallas, TX: SIL International.

Li, G. (2006). Biliteracy and trilingual practices in the home context: Case studies of ChineseCanadian children. Journal of Early Childhood Literacy, 6(3), 355-381.

Lo Bianco, J., \& Peyton, J.K. (2013). Vitality of heritage languages in the United States. Heritage Language Journal, 10(3), i-viii. 
Méndez, L. I., Crais, E. R., Castro, D. C., \& Kainz, K. (2015). A culturally and linguistically responsive vocabulary approach for young Latino dual language learners. Journal of Speech, Language, and Hearing Research, 58(1), 93-106.

Mayer, M. (1969). Frog, where are you? New York NY: Dial Press.

Nesteruk, O. (2010). Heritage language maintenance and loss among the children of Eastern European immigrants in the USA. Journal of Multilingual and Multicultural Development, 31(3), 271-286.

Oh, J. S., \& Fuligni, A. J. (2010). The role of heritage language development in the ethnic identity and family relationships of adolescents from immigrant backgrounds. Social Development, $19(1), 202-220$.

Oriyama, K. (2010). Heritage language maintenance and Japanese identity formation: What role can schooling and ethnic community contact play? Heritage Language Journal, 7(2), 76-111. Available from http://www.heritagelanguages.org

Otcu, B. (2010). Heritage language maintenance and cultural identity formation: The case of a Turkish Saturday school in New York City. Heritage Language Journal, 7(2), 112-137. Available from http://www.heritagelanguages.org

Pavlenko, A. (2009). Conceptual representation in the bilingual lexicon and second language vocabulary learning. The bilingual mental lexicon: Interdisciplinary approaches, 125-160.

Pak, H.R. (2003) When MT is L2: The Korean church school as a context for cultural identity. In Hornberger, N.H. (Ed.), Continua of biliteracy: An ecological framework for education policy, research, and practice in multilingual settings (pp. 269-290) Clevedon, England/Buffalo, NY: Multilingual Matters.

Park, S. M., \& Sarkar, M. (2007). Parents' attitudes toward heritage language maintenance for their children and their efforts to help their children maintain the heritage language: A case study of Korean-Canadian immigrants. Language, culture and curriculum, 20(3), 223-235.

Polinsky, M. (2006). Incomplete acquisition: American Russian. Journal of Slavic Linguistics, 191-262.

Polinsky, M., \& Kagan, O. (2007). Heritage languages: In the 'wild' and in the classroom. Language and Linguistics Compass, 1(5), 368-395.

Polinsky, M. (2008). Heritage language narratives. In: Brinton, D., Kagan, O. \& Bauckus, S. (Eds.), Heritage language education: A new field emerging (pp. 149-164). New York, NY: Routledge.

Polinsky, M., \& Kagan, O. (2007). Heritage languages: In the 'wild' and in the classroom. Language and Linguistics Compass, 1(5), 368-395.

Protassova, E. (1997). Transition from babbling to word structure. Papers and Studies in Contrastive Linguistics, 33, 153-158.

Protassova, E. (2008). Teaching Russian as a heritage language in Finland. Heritage Language Journal, 6(1), 127-152. Available from http://www.heritagelanguages.org

Protassova, E. (2018). Longing for quality: Experiences of Finnish-Russian bilingual kindergarten in Finland. In Schwartz, M. (Ed.). Preschool bilingual education: Agency in interactions between children, teachers, and parents (pp. 135-162). Series Multilingual Education. Dordrecht, The Netherlands: Springer.

Protassova, E., Mäki, M., \& Rodina, N. (2017). Eksperimental'noe issledovanie osvoenija russkix padezhej det'mi-bilingvami v Finljandii [An experimental study of Russian case acquisition by bilingual children in Finland]. Acta Linguistica Petropolitana XIII(3), 774-788. 
Schwartz, M. (2008). Exploring the relationship between family language policy and heritage language knowledge among second generation Russian-Jewish immigrants in Israel. Journal of Multilingual and Multicultural Development, 29(5), 400-418.

Schwartz, M. (2010). Family language policy: Core issues of an emerging field. Applied Linguistics Review, 1(1), 171-192.

Schwartz, M., Moin, V., Leikin, M., \& Breitkopf, A. (2010). Immigrants' family language policy toward children's preschool bilingual education: Parents' perspective. International Multilingual Research Journal, 4, 107-124.

Schwartz, M. (2014). The impact of the first language first model on vocabulary development among preschool bilingual children. Reading and Writing, 27(4), 709-732.

Schwartz, M., \& Minkov, M. (2014). Russian case system acquisition among Russian-Hebrew speaking children. Journal of Slavic Linguistics, 22(1), 51-92.

Schwartz, M., Minkov, M., Dieser, E., Protassova, E., Moin, V., \& Polinsky, M. (2015). Acquisition of Russian gender agreement by monolingual and bilingual children. International journal of bilingualism, 19(6), 726-752.

Schwartz, M., Moin, V., Leikin, M., \& Breitkopf, A. (2010). Immigrants' family language policy toward children's preschool bilingual education: Parents' perspective. International Multilingual Research Journal, 4, 107-124.

Shibata, S. (2000). Opening a Japanese Saturday school in a small town in the United States: Community collaboration to teach Japanese as a heritage language. Bilingual Research Journal 24(4), 465-74.

Spolsky, B. (2004). Language Policy. Cambridge, UK: Cambridge University Press.

Statistics Finland (2018). PX-Web databases. Population by Language and Year 31.12.2017. www.tilastokeskus.fi

Timberlake, Alan. (2004) A reference grammar of Russian. Cambridge, UK: Cambridge University Press.

UNESCO. (2009). UNESCO Atlas of the World's Languages in Danger. Retrieved from www.unesco.org/culture/ich/index.php?pg=00139

U.S. Census Bureau. (2018). Table B16001: Language spoken at home by ability to speak English for the population 5 years and over for United States [Data table]. American Community Survey 2013-2017 5-year estimates. Washington, DC: United States Census Bureau. Available from http://www.census.gov

Valdés, G. (2000). The teaching of heritage languages: An introduction for Slavic-teaching professionals. The learning and teaching of Slavic languages and cultures, 375-403. Bloomington, IN: Slavica.

Valdés, G. (2001). Heritage Language Students: Profiles and Possibilities. In J.K. Peyton, D.A. Ranard, \& S. McGinnis (Eds.), Heritage languages in America: Preserving a national resource (pp. 37-77). Washington DC: Center for Applied Linguistics.

Van Deusen-Scholl, N. (2003). Toward a definition of heritage language: Sociopolitical and pedagogical considerations. Journal of language, identity, and education, 2(3), 211-230.

Wiley, T.G. (1996). Literacy and language diversity in the United States. McHenry, IL: Delta Systems Co., Inc./Washington, DC: Center for Applied Linguistics.

Witzlack-Makarevich, K., \& Wulff, N. (Eds.). (2017). Handbuch des Russischen in Deutschland: Migration-Mehrsprachigkeit-Spracherwerb (vol. 5). Berlin, Germany: Frank \& Timme. 
WSB (2016). Wissenshaftliche Dienste des Bundestages, [Scientific Services of the Bundestag], https://www.bundestag.de/blob/424502/e534deaef41f3f1f1efcf098f64cb013/wd-3-036-16pdf-data.pdf

Yearbook of Immigration Statistics: 2016. Washington, D.C. U.S. Department of Homeland Security.

Zaliznjak, A. (1977). Grammatičeskij slovar’ russkogo jazyka [Grammatical dictionary of the Russian language]. Moscow, Russia: Russkij jazyk.

Zaliznjak, A.(2002) Russkoe imennoe slovoizmenenie [Russian nominal inflection]. Moscow, Russia: Jazyki slavjanskoj kultury. 


\section{APPENDIX}

\section{Questionnaire $\quad \mathbf{1 0 . 2 0 1 4}$}

If you speak Russian at home, were born in the host country or came before you were seven, please answer these questions. If you are under 18 years old, your parents need to sign the consent below.

Name:

Date:

Please provide the following information

1. Place and date of birth:

2. Gender:

2. If foreign born, how old were you when you came to the host country?

3. What is your parents' highest level of education (please, circle one)?

a. elementary school education

b. high school graduate

c. college graduate

f. university degree

h. other

3. Have you had any instruction in Russian in the host country:

3a. Where and in what context (please, circle all relevant options):

at after school classes/formal bilingual school

4.What language/s (please, tick your responses below):

\begin{tabular}{|l|l|l|l|}
\hline & Russian & Host language & $\begin{array}{l}\text { Russian and host } \\
\text { language }\end{array}$ \\
\hline $\begin{array}{l}\text { 1. What language/s } \\
\text { do your parents } \\
\text { use between } \\
\text { them? }\end{array}$ & & & \\
\hline $\begin{array}{l}\text { 2. What language/s } \\
\text { do your parents } \\
\text { use with you? }\end{array}$ & & & \\
\hline
\end{tabular}




\begin{tabular}{|l|l|l|l|}
\hline 3. What language/s \\
$\begin{array}{l}\text { do you use with } \\
\text { your parents? }\end{array}$ & & & \\
\hline 4. What language/s & & & \\
$\begin{array}{l}\text { do you use with } \\
\text { your friends? }\end{array}$ & & & \\
\hline
\end{tabular}




\section{NoTES}

1. In this paper we use the terms "after-school classes"” and "community school" interchangeably.

2. The "baseline" is usually viewed as the language represented by a monolingual native speaker.

3. Russian linguists distinguish several additional cases, which are either incomplete (apply only to several nouns) or identical to one of the six basic cases (see Zaliznjak, 2002, for discussion).

4. The classification of declensions may vary among Russian linguists.

5. The numbering of the first and second declensions may vary, i.e., in some surveys the first declension is named the "second" and vice versa.

6. Although monolinguals acquire the basic case system by the age of three, in the case of the HSs, especially with early onset of bilingualism, the case system undergoes reduction and simplification (Polinsky 2006, 2008). Therefore, these participants were treated as not different from those who were born in the host country and were not excluded from the study.

7. A high level of education among parents is typical of immigrants from the former Soviet Union (e.g., Ben-Rafael et al., 2006).

8. Note that this sentence is correct grammatically, but still does not correspond to the norms of Russian syntax.

9. It is noteworthy that all our participants reported speaking Russian with grandparents living in the host countries and in the former Soviet Union; therefore, we did not compare the groups on this variable.

10. By "mixed use," we mean situations in which children used both languages with their parents, whereas parents could use either both languages or only Russian. 